\title{
How large is the firm-specific component of German apprenticeship training?
}

\author{
Harald Pfeifer ${ }^{\mathrm{a}^{*}}$, Gudrun Schönfeld ${ }^{\text {a }}$, Felix Wenzelmann ${ }^{\mathrm{a}}$ \\ ${ }^{a}$ Federal Institute for Vocational Education and Training (BIBB)
}

\begin{abstract}
In this paper, we use unique firm-level data to calculate a monetary value of the firm-specific component of German apprenticeship training. We do this by comparing the initial productivities and wages of externally recruited and internally trained workers in the same job, occupation and firm. We argue that the resources needed to increase the productivity of externally recruited workers to the level of internally trained workers are an adequate measure of the firmspecificity of training. We also calculate the firm-specific component as a share of total investment in human capital during apprenticeship training. Our results support the view that German apprenticeship training is mainly general, with an average specific share of $12 \%$ of total human capital investments. The share, however, increases with firm size and differs between occupational fields.
\end{abstract}

JEL Classification: J24

Keywords: Apprenticeship training, costs and benefits of training, firm-specific human capital

\section{Introduction}

Classical human capital theory (Becker, 1962) claims that under perfect market conditions firms do not invest in general human capital. In response to this claim, Acemoglu and Pischke (1998, 1999a, b) develop a model explaining why firms may have incentives to do so. As an empirical example, the authors refer to the case of apprenticeship training in Germany, for which several surveys have shown that, on average, firms bear substantial training costs (von Bardeleben et al., 1995; Beicht et al., 2004; Schönfeld et al., 2010). An important assumption made by Acemoglu and Pischke is that apprenticeship training generates mainly general skills because apprentices are required to follow a prescribed curriculum, take an outside examination at the end of the training period and receive a nationally recognised certificate issued

* Corresponding author: harald.pfeifer@bibb.de. The authors thank Hans Heijke, Ben Kriechel, Günter Walden, Stefan C. Wolter and an anonymous referee, as well as the participants in the 14th Colloquium on Personnel Economics held in Zurich on the 9th to 11th of February 2011 and in the 2nd Congress on Research in Vocational Education and Training held in Berne/Zollikofen on the 23rd to 25th of March 2011, for helpful comments. 
by the respective industry or craft chamber. In practice, however, it is possible for firms to influence the content of apprenticeship training. In the dual system of training, apprentices spend only one or two days of the working week in a vocational school. During the remainder of the week, training takes place within the firm, giving firms substantial scope to foster skills that are specific to the firm. Consequently, it is possible that at least a fraction of the skills obtained during apprenticeship training in a firm are not directly transferable to other firms. While firm investment in German apprenticeship training has been extensively analysed in the surveys referenced above, the degree of firm-specificity of training has not yet been estimated directly on the basis of representative firm-level data.

In addition to the fact that the degree of firm-specificity of apprenticeship training is interesting from a scientific perspective, the results presented in this paper may also be important from a political point of view. For a long time, the primary goal of political leadership and social partners has been to offer young apprentices a transparent and transferable education. Since the early 1990s, however, the call for more freedom in tailoring apprenticeship training to individual firms' skill needs has intensified, and this has led to the adoption of less stringent training regulations. The question arises of whether German firms have, in general, taken advantage of the freedom so provided to introduce firm-specific elements in their training to safeguard their human capital investments against the risk of poaching in increasingly competitive labour and product markets.

In this paper, we use data from the Cost-Benefit-Survey (CBS) conducted by the Federal Institute for Vocational Education and Training (BIBB) of 2007 to calculate a monetary value for the firm-specific component of German apprenticeship training. We compare the initial productivity and wages of externally recruited workers to those of internally trained workers in cases where both groups have been trained in the same occupation, perform the same type of job and are employed in the same firm. We argue that the amount of a firm's resources that is needed to raise the productivity of externally recruited workers to the level of those who were trained internally provides a good measure of the magnitude of the firm-specific training component. Because both externally recruited and internally trained workers are required to pass a standardised, external examination in their respective occupations (BMBF, 2005), we make the explicit assumption that apprentices in the same occupation receive a similar amount of general and occupation-specific training. ${ }^{1}$ Consequently, differences in productivity between internally trained and externally recruited workers in the same type of job, occupation and firm must result from differences in the endowment of non-transferable, i.e. firm-specific, skills. To estimate the monetary value of this specific component, we use firm-level information on the relative productivity, adjustment time, direct and indirect continuing training costs and wages received by the respective groups of workers. In a second step, we calculate the specific training component as a share of the firms' total investment in human capital

1 Occupation-specific skills are treated as de facto general human capital in this paper because these skills can also be transferred to other firms employing persons with the same occupation.. 
generated by apprenticeship training. We approximate the total investment based on the costs of training personnel, training infrastructure and training organisation. Finally, we use a Heckman-type selection model to regress the share of firm-specific training on a number of explanatory variables to analyse its determinants.

The remainder of this paper is structured as follows. In section 2, we reflect upon theoretical aspects of the problem and briefly discuss the relevant literature. In section 3, we describe the data source and the method used to calculate the absolute value of firm-specific training components and the gross cost of training. Our empirical strategy and selection issues are discussed in section 4 . The results are given in section 5 , and section 6 concludes the paper.

\section{Theoretical background and literature}

Becker (1962) concluded from a theoretical analysis that firms would refrain from investment in general training. To recoup the costs related to general training, firms would need to pay trained workers wages below their marginal product. In a perfect labour market, workers would not accept this and would move to a firm willing to pay the market wage. In the case of firm-specific training, in contrast, it is rational for firms to invest in training because the additional skills acquired by workers during such training are applicable only in the training firm and do not increase the marginal product elsewhere. In this case, the firm can pay wages below the workers' marginal product and in this way recoup the cost of training. ${ }^{2}$ Acemoglu and Pischke $(1998,1999 \mathrm{a}, \mathrm{b})$, among others, have argued that firm investment in general human capital is rational if a) labour market frictions distort the equality of wages and productivity and b) a compressed wage structure leads to an increasing gap between wages and productivity along the training dimension. Firms are thus able to reap a benefit from general training without risking the loss of trained workers to another firm. Leuven (2005) supplies an overview of the relevant theories with respect to private sector training. Wolter and Ryan (2011) offer a comprehensive survey of theoretical and empirical issues related to apprenticeship training.

An important question discussed in the aftermath of Becker's work is whether it is possible to distinguish between general and firm-specific skills. According to Bishop (1996), all skills may be general, but each worker has a particular mix of skills. This mix may be more useful to the current employer than to alternative employers, and this encourages the employer to invest in the skill mix that she requires. Lazear (2009) formalises this argument in his «Skill-Weights Approach». ${ }^{3}$ Similarly, Stevens (1994) argues that, in practice, skills are neither completely general nor

2 Becker (1962) and later Hashimoto (1981) argue that the investment in firm-specific human capital is shared between the worker and the firm.

3 Although this paper focuses on the firm-specific training component, we could easily transfer the analysis to this strand of thought. The absolute value of raising the productivity of an externally recruited worker and its share in total human capital investments, which is calculated in section 4, could be interpreted as the productivity loss due to differences between the skill mix needed by the firm and the mix offered by the recruited worker. 
purely specific. This mixture of skills makes the outside market for workers noncompetitive and therefore fosters firm investment in training. Franz and Soskice (1995) and Kessler and Lülfesmann (2006) point out that from the employer's point of view, general and specific skills may be complementary. Teaching firm-specific skills may reduce the cost of also teaching general skills and vice versa. As empirical evidence for firm investment in general training, Acemoglu and Pischke (1998, $1999 \mathrm{a}, \mathrm{b})$ refer to the German apprenticeship system. ${ }^{4}$ A series of micro-level surveys has shown that firms incur substantial net costs when training apprentices (von Bardeleben et al., 1995; Beicht et al., 2004). The most recent of these surveys for the reference year 2007, which also provides the data for the analysis conducted in this paper, confirms these results (Schönfeld et al., 2010). ${ }^{5}$ One of the few studies that directly identifies firm-specificity is that of Schweri (2006), who uses the Swiss data set on costs and benefits of vocational training (reference year 2000) to analyse the impact of the degree of firm-specificity on training decisions and training costs. He finds that firm-specificity has no significant impact on the training decisions of firms. Furthermore, he finds no clear evidence that a higher degree of firm-specificity induces firms to accept higher training costs. ${ }^{6}$

In addition to the Swiss study, a number of studies have analysed the importance of firm-specific training in German apprenticeship training. Most of these studies investigate labour market outcomes, such as wages and mobility of former apprentices, to draw conclusions about the relative importance of the firm-specific training component. Werwatz (1996) finds that apprentices who leave the training firm experience no substantial earnings loss compared to apprentices who remain in the firm. He concludes that overall, apprenticeship training does not have a strong firm-specific component. For large firms in the industry sector of the economy, however, the firm-specific component seems to be higher than in small firms in the craft sector. Clark (2001) and Clark and Fahr (2002) show that former apprentices experience no significant wage cuts after moving to another firm, at least if they stay within their broad occupational group. The authors conclude that apprenticeship training is highly transferable and thus mainly general. Korpi and Mertens (2003) also deduce from their analysis of mobility patterns in Germany and Sweden that «the proportion of truly firm-specific skills acquired during a German apprenticeship is rather low in relation to the transferable skills obtained» (p. 613). Euwals and Winkelmann (2004) confirm previously published studies in that they find no systematic wage differential between stayers and movers. On the other hand, Bougheas and Georgellis (2004) find that apprentices who leave the training firm experience an earnings loss that the

4 Autor (2001) provides empirical evidence for general training investments by temporary help agencies in the United States.

5 Using the two latest BIBB-CBS waves, Pfeifer et al. (2010) show that net training costs have dropped significantly, even when controlling for structural changes and business cycle variations.

6 As a proxy for firm-specificity, Schweri uses the product of adaption time in months and the relative productivity of externally recruited workers. Although these measures are also important factors in the calculation in the present paper, we calculate the cost for adaption using the respective wages, as formalised in section 3.2. 
authors attribute to the loss of firm-specific human capital. However, movers' earnings grow at a faster rate than those of stayers over the time spent in the labour market. Using Lazear's «Skill-Weights Approach», Backes-Gellner et al. (2010) find that the more specific the skill portfolio in an occupation is, the higher the net costs firms bear for apprenticeship training in the respective occupations. The same analytical framework is used by Geel and Backes-Gellner (2011) to analyse the specificity of skill combinations of various occupations and the effects of such specificity on occupational mobility and wages.

An important drawback of a number of the cited studies is that movers can stay within a broad occupational group but perform a different type of job that requires a different set of skills. Thus, the loss in earnings of movers compared to stayers may be attributable to the fact that some movers cannot use the full set of general skills obtained in the training firm. In addition, firms may be forced, through collective bargaining agreements for example, to accept lower productivity during the recruited workers' adjustment period without being able to adjust wages accordingly. In addition, (lower) wages are only one part of the story. Costs for continuing training measures aimed to increase the productivity of newly hired workers are not accounted for in the above studies. Consequently, there could be a loss of firm-specific human capital of movers that is not reflected in their initial wages.

To contribute to the existing literature in this area, the present paper draws from rich data on the wage and productivity differences of internally trained and externally recruited workers. Further training costs for externally recruited workers are also measured in detail. Finally, we are able to observe movers and stayers not only in the same occupation and firm but also performing the same type of job. We thereby avoid some of the drawbacks of the studies cited above. The data source used and the construction of variables are described in detail in the subsequent section.

\section{Data source and calculation method}

\subsection{BIBB-Cost-Benefit-Survey}

The data used in our analysis stem from the 4th BIBB-Cost-Benefit-Survey (BIBBCBS) conducted for the reference year 2007. Representatives from a total of 2958 firms answered a detailed questionnaire during a computer-assisted personal interview (CAPI). The respondents were usually firm employees responsible for the training of apprentices and/or were personnel managers. In the case of small firms, the interview partners often were the owners of the business. The data set contains unique information about the firms' training costs and benefits, and the firms were asked to supply information about one specific occupation trained. Altogether, 51 of the most common occupations were surveyed.

In addition to providing cost information, firms that had recruited already-trained workers from the external labour market over the last three years answered a set of additional questions. The answers to these questions provided information on pro- 
ductivity and wage differences between externally recruited and internally trained workers. In addition, detailed information about the adjustment time and continuing training costs for externally recruited workers was given. In the descriptive analysis of the data, we focus on the subset of firms that recruited workers from the external labour market to fill positions in which they performed jobs similar to those of internally trained workers. This data set includes about 800 firms. Descriptive information about this sample and the entire sample of firms is given in table A1.

\subsection{Variable construction}

In an initial step, we calculate an indicator of total investment in human capital during apprenticeship training for the single firm $T H C_{\mathrm{i}}$. The indicator includes three main components. The first component is the cost of training personnel involved in the training of apprentices. For this component, we use information about the average hours, $h_{\mathrm{i}}^{\mathrm{t}}$, that trainers spend with apprentices and multiply these by the hourly wage, $w_{\mathrm{i}}^{\mathrm{t}}$, of trainers. Trainers can either be full-time training staff, unskilled workers, skilled workers or members of the firm's management. For each of these subgroups of trainers, we draw on separate information for hours spent and wages paid.

The second component entails costs for the firm that are related to the infrastructure of training, $I_{i}$. Firms can have separate training centres in which apprentices can practice. Several firms make use of internal classroom teaching. The rent and costs for maintenance, equipment and furniture of these facilities are included in the costs for infrastructure. We also include costs for tools, machines and materials used in training.

The third component consists of costs related to the organisation, coordination and administration of training, $O_{\mathrm{i}}$. This indicator takes account of costs for external training courses and administrative costs for apprentices. These three components can be used to calculate the total investment in human capital over the entire apprenticeship period of three (or three and one-half) years for firm $i$. Formalising the calculation of $T H C_{\mathrm{i}}$ yields the following equation:

$T H C_{\mathrm{i}}=h_{\mathrm{i}}^{\mathrm{t}} w_{\mathrm{i}}^{\mathrm{t}}+I_{\mathrm{i}}+O_{\mathrm{i}}$

Table A2 displays the respective monetary values for both samples of firms. It is important to note that the indicator $T H C_{\mathrm{i}}$ cannot be compared to the indicator of gross costs of training used in Schönfeld et al. (2010) because the methods used to calculate the two indicators differ. The indicator of human capital investments that is presented here excludes wages paid to the apprentices because these wage costs are not directly linked to human capital formation but rather could be viewed as compensation for the productive contribution of apprentices. In addition, the indicator in this paper has a higher value of costs for training personnel because all hours spent with the apprentice are valued with the respective wages of trainers. In the gross costs calculated in Schönfeld et al. (2010), only training hours are considered to lead to costs, which effectively reduces the productivity of trainers. We use this method 
of calculation because our aim is to develop an indicator approximating the monetary «input» into human capital formation rather than to focus on a pure cost-benefit description of training from the firms' perspective.

In the second step of the calculation, our main variable of interest, the monetary indicator for firm-specificity of apprenticeship training on the firm level $S H C_{\mathrm{i}}$, is constructed. For the calculation of $S H C_{\mathrm{i}}$, we first calculate the adjustment costs over the time during which the externally recruited worker is in the firm but has a lower productivity than an internally trained worker. To do this, we use information about the relative productivity level $p_{\mathrm{ti}}^{\mathrm{r}}$ of the externally recruited worker in month $t ; p_{\mathrm{ti}}^{\mathrm{r}}$ has a value between 0 and $1 .^{7}$ The productivity difference between the two groups of workers is then defined as $1-p_{\mathrm{ti}}^{\mathrm{r}}$. Using information about the wage $w_{\mathrm{i}}^{\mathrm{ex}}$ of the externally recruited worker, we then calculate the adjustment costs for each month $t$ over the period of adjustment $a_{\mathrm{i}}$, which is also available in the data set. ${ }^{8}$ In this model, we assume that the externally recruited worker's productivity improves linearly over the adjustment period. Adjustment $\operatorname{costs} c_{\mathrm{i}}^{\mathrm{a}}$ for the individual firm are thus determined by

$c_{\mathrm{i}}^{\mathrm{a}}=\sum_{t=1}^{a_{\mathrm{i}}}\left(w_{\mathrm{i}}^{\mathrm{ex}}-w_{\mathrm{i}}^{\mathrm{int}} * p_{\mathrm{ti}}^{\mathrm{r}}\right)$

Note that equation 2 is an approximation of

$c_{\mathrm{i}}^{\mathrm{a}}=\sum_{t=1}^{a_{\mathrm{i}}}\left(\left(\phi_{\mathrm{i}}^{\mathrm{int}}-w_{\mathrm{i}}^{\mathrm{int}}\right)-\left(\phi_{\mathrm{ti}}^{\mathrm{ex}}-w_{\mathrm{i}}^{\mathrm{ex}}\right)\right)$

where $\phi_{\mathrm{i}}^{\mathrm{int}}$ is the productivity of internally trained workers and $\phi_{\mathrm{ti}}^{\mathrm{ex}}=\phi_{\mathrm{i}}^{\mathrm{int}} * p_{\mathrm{ti}}^{\mathrm{r}}$ is the productivity of externally recruited workers in month $t$. Because $\phi_{\mathrm{i}}^{\text {int }}$ is unknown and assumed to be constant over time, we approximate the productivity of internally trained workers by their wage. ${ }^{9}$ Furthermore, direct costs and indirect costs for continuing training are calculated; the direct $\operatorname{costs}, c_{\mathrm{i}}^{\mathrm{d}}$, consist of fees and expenses for the firm, and the indirect wage $\operatorname{costs} c_{\mathrm{i}}^{\mathrm{w}}$ are the wage costs arising from the absence of the externally recruited workers during external training. Continuing training costs are then given by:

$c_{\mathrm{i}}^{\mathrm{t}}=c_{\mathrm{i}}^{\mathrm{d}}+c_{\mathrm{i}}^{\mathrm{w}}$

The monetary indicator for the firm-specific component of training, then, is the sum of adjustment costs and further training costs:

6 The exact wording of the question is the following: «How much lower is the productivity of the externally recruited worker compared to that of the internally trained worker in the same (or similar) occupation working in the same (or similar) type of job at the beginning of the adjustment time?»

7 The exact wording of the question is the following: «How long (in months) does the adjustment period of the externally recruited worker last?»

8 Because in imperfect labour markets wages could be below productivity, a different set of results could be obtained for the adjustment cost value and the estimate of the firm-specific training component. We therefore offer a set of alternative calculations in sections 4 and 5 and in the appendix. 
$S H C_{\mathrm{i}}=c_{\mathrm{i}}^{\mathrm{a}}+c_{\mathrm{i}}^{\mathrm{t}}$

Finally, the monetary indicator for the firm-specific training component is divided by the total investment in human capital, yielding the share of the firm-specific component share $_{\mathrm{i}}$.

share $_{\mathrm{i}}=S H C_{\mathrm{i}} / T H C_{\mathrm{i}}$

Table A3 provides descriptive information on the relevant variables for the sample of recruiting firms.

\section{Empirical strategy}

\subsection{Precision of estimates}

The strategy employed is to first calculate the share of firm-specificity and compare it across a number of structural variables. However, before discussing the results, we need to address potential problems associated with the precision of our estimates. The calculation method proposed in this paper applies only under the assumption that, on average, apprentices who pass the outside training examination in a specific occupation possess similar stocks of general and occupation-specific human capital and that internally trained workers differ from externally recruited workers only with respect to their firm-specific skills. The method also relies on the assumption that internally trained and externally recruited workers do not differ systematically in innate ability and motivation. Because the data at hand offer no information about the employment history of externally recruited workers, these are strong assumptions; they can be challenged by arguing that the more able apprentices tend to stay in the training firm while the less able (i.e. the «lemons») are released onto the labour market. On the other hand, the average ability of externally recruited workers could be higher than that of internally trained workers if the former group consists mainly of «poached» workers. In such a case, the firm-specific training component may in fact be larger than is estimated below. However, if the average ability of externally recruited workers is lower than that of internally trained workers, our results can be interpreted as an upper bound for the share of the firm-specific component.

Another point to be discussed at this stage is the lack of data on the productivity of internally trained employees. In section 3.2, we valued productivity differences with the wage of the internally trained employee. Models of imperfect competition predict, however, that wages paid by firms are below the workers' productivity. If this is the case, our value for the adjustment $\operatorname{costs} c_{\mathrm{i}}^{\mathrm{a}}$ of firm $i$ would be underestimated. Apart from the baseline calculations discussed below, we therefore recalculated the model, assuming differences between productivity and wages of 10\%,25\% and 50\%. The results are given in table A6 and are briefly discussed below. 


\subsection{Sample selection model}

For the second step of the empirical strategy, the analysis of the determinants of firm-specificity in a regression framework, we must take into account that restricting the analysis to a subsample of training firms that have recruited personnel over the last three years (i.e. from 2005 to 2007) may cause a selectivity problem. It is possible that the samples we have chosen to represent recruiting and non-recruiting firms differ not only in observed but also in unobserved characteristics that also relate to the firm-specific component of training. An unobserved variable could be, for example, the specialisation of firms in niche products. Recruiting personnel from the external labour market would be too costly for such firms because the production of niche products requires highly specific skills that are difficult to learn within an acceptable time period. It would be more beneficial for such firms to train apprentices and use the time the apprentices spend in the firm to invest in production-specific skills. In this case, specialising in niche products would be an omitted variable that impacts (negatively) the likelihood that the firm will recruit workers from the external labour market and at the same time impacts (positively) the share of firm-specific training. Neglecting such a relationship, if present, would lead to underestimation of the firm-specificity of training due to sample selection.

In order to obtain consistent estimates, we therefore follow a maximum-likelihood selection model frequently used in the literature (see Heckman, 1979). In this model, the selection variable is the recruitment of trained workers and the main dependent variable is the share of firm-specific training. To identify the model, we need to include exclusion restriction variables in the selection equation. The choice of such variables is delicate in the sense that they should be both theoretically well founded and statistically valid, i.e. they must be correlated with the recruitment of trained workers from the external labour market but must not be correlated with the share of firm-specific training.

We choose two variables that measure a) the development of the workforce in the firm and b) whether or not the firm was able to fill all vacant apprenticeship-training slots during the past three years. The reason for choosing variable a) is that the increase in the number of workers reflects the economic success of the firm and should be highly correlated with external recruitment but not with the firm-specific component of apprenticeship training. The reason for choosing variable $b$ ) is that firms that could not fill all training slots are more likely to recruit from the external labour market. At the same time, the fact that a firm could not fill all its available training slots is not likely to be correlated with the firm-specific component of training.

However, it could be the case that, in the situation of a tight labour market, firms recruit workers that are less qualified because an insufficient number of workers with matching qualifications are available. The productivity of such employees would be lower than the productivity of those with a better qualification match. This scenario would lead to higher adjustment costs and a larger share of firm-specific human 
capital. A similar argument applies with respect to the variable of unfilled training slots. Firms that are not able to fill all training slots could be firms that are less attractive to qualified workers on the labour market. These firms may be forced to recruit workers with lower ability than firms without problems filling apprenticeship vacancies. Again, the firm-specific component would be larger. In both cases, the independence of our exclusion restriction from firm-specificity would be violated.

To address this problem, we supply unemployment and open vacancy time series statistics from the Federal Employment Agency in Germany (see figure A1). The reference years for our sample are the three years prior to the survey, i.e. the years 2005 to 2007. As the figure indicates, unemployment fell from 2005 onwards from an all-time peak of close to 5 million registered unemployed to under 4 million registered unemployed. At the same time, job vacancies registered at the Federal Employment Agency increased over that period from a relatively low level. In total, the figure indicates that unemployment was still substantial and that job vacancies were not extraordinarily high during the reference period; this does not lend support to the idea that labour markets were especially tight at that time. We further make use of a survey question that aims to measures the availability of skilled workers on the external labour market from the viewpoint of the single firm..$^{10}$ The correlation between this variable and our measures for productivity and the share of firm-specific training is close to zero (0.008 and 0.013 , respectively). Thus, the availability of skilled workers on the external labour market is statistically not related to our outcome measures. Finally, we check whether our exclusion restriction variables are correlated with productivity and firm-specificity. Table A4 shows that this is not the case. The correlation between the two selection variables and the outcome variables is close to zero. On the basis of this information, we conclude that our exclusion restrictions are valid instruments for identifying our model.

In addition to the exclusion restriction variables, we include a set of explanatory variables, such as firm size (four categories) and region. We also add two institutional variables. The first is a dummy indicating the existence of a works council in the firm, and the second indicates whether the firm is bound to collective wage agreements. Because the number of cases for some of the 51 occupations included in the survey is relatively low, we aggregate the occupational information according to the common classification of occupations. This classification results in 12 occupational groups; these groups are also included in the set of explanatory variables.

\section{Results}

Table 1 displays the results of the calculation of firms' total investment in human capital during apprenticeship training THC (column 1) and the monetary value of the firm-specific component SHC (column 2). In column 3, the calculated firm-specific component of apprenticeship training is presented as share of total investment

9 The exact wording of the question is: «How would you judge the number of available skilled workers in the training occupation?» Answering options were from 1 «very good» to 5 «very poor». 
(share). On average, the share of firm-specific training is relatively low, with a value of $12 \%$. Differentiating between firms of different sizes shows that apprenticeship training in large firms with more than 500 employees is more specific than training in small firms with up to 10 employees. While the average value for the former is $21 \%$, the firm-specific component for the latter is about $9 \%$ of total human capital investments. Notable differences also exist with respect to occupational groups. Firms that train workers in health occupations such as medical assistant or dental assistant and occupations in the fields of accommodation and food, such as cook or baker, have a low share of firm-specificity in training of about $6 \%$. For firms that train workers in occupations such as banking and insurance or chemicals, this measure is relatively high ( $25 \%$ and $21 \%$, respectively). Differences in firm-specificity by region are negligible, whereas firms with a works council have relatively high firmspecific training components.

Table 1: Firm investment in human capital and the firm-specific component of apprenticeship training

\begin{tabular}{|c|c|c|c|}
\hline & $\begin{array}{c}\text { Firm investment } \\
\text { in human capital } \\
T H C\end{array}$ & $\begin{array}{l}\text { Monetary value } \\
\text { for firm-specific } \\
\text { training } S H C\end{array}$ & $\begin{array}{c}\text { Share of } \\
\text { firm-specific } \\
\text { training* }\end{array}$ \\
\hline \multicolumn{4}{|l|}{ Firm size } \\
\hline 1-9 employees & $\begin{array}{c}52884 \\
(40521)\end{array}$ & $\begin{array}{c}2971 \\
(4026)\end{array}$ & $\begin{array}{c}0.09 \\
(0.17)\end{array}$ \\
\hline 10-49 employees & $\begin{array}{c}41422 \\
(35887)\end{array}$ & $\begin{array}{c}3042 \\
(3288)\end{array}$ & $\begin{array}{c}0.13 \\
(0.17)\end{array}$ \\
\hline 50-499 employees & $\begin{array}{c}39961 \\
(31984)\end{array}$ & $\begin{array}{c}4597 \\
(4566)\end{array}$ & $\begin{array}{c}0.19 \\
(0.22)\end{array}$ \\
\hline $500+$ employees & $\begin{array}{c}45230 \\
(38235)\end{array}$ & $\begin{array}{c}4979 \\
(3649)\end{array}$ & $\begin{array}{c}0.21 \\
(0.24)\end{array}$ \\
\hline \multicolumn{4}{|l|}{ Vocational field } \\
\hline Metalworking & $\begin{array}{c}50398 \\
(37085)\end{array}$ & $\begin{array}{c}3575 \\
(4330)\end{array}$ & $\begin{array}{c}0.12 \\
(0.20)\end{array}$ \\
\hline Electrical engineering & $\begin{array}{c}51159 \\
(37299)\end{array}$ & $\begin{array}{c}3753 \\
(4216)\end{array}$ & $\begin{array}{c}0.12 \\
(0.19)\end{array}$ \\
\hline Information technology & $\begin{array}{c}57272 \\
(35471)\end{array}$ & $\begin{array}{c}5010 \\
(3131)\end{array}$ & $\begin{array}{c}0.13 \\
(0.13)\end{array}$ \\
\hline Chemicals & $\begin{array}{c}36716 \\
(28610)\end{array}$ & $\begin{array}{c}5400 \\
(4336)\end{array}$ & $\begin{array}{c}0.21 \\
(0.22)\end{array}$ \\
\hline Accommodation and food & $\begin{array}{c}40413 \\
(30236)\end{array}$ & $\begin{array}{c}1385 \\
(1420)\end{array}$ & $\begin{array}{c}0.06 \\
(0.08)\end{array}$ \\
\hline Construction & $\begin{array}{c}48147 \\
(50754)\end{array}$ & $\begin{array}{c}3028 \\
(3394)\end{array}$ & $\begin{array}{c}0.15 \\
(0.27)\end{array}$ \\
\hline Print and media & $\begin{array}{c}50219 \\
(38826)\end{array}$ & $\begin{array}{c}2878 \\
(6592)\end{array}$ & $\begin{array}{c}0.08 \\
(0.16)\end{array}$ \\
\hline Health & $\begin{array}{c}59019 \\
(32783)\end{array}$ & $\begin{array}{c}2352 \\
(2264)\end{array}$ & $\begin{array}{c}0.06 \\
(0.06)\end{array}$ \\
\hline
\end{tabular}




\begin{tabular}{|c|c|c|c|}
\hline \multirow{2}{*}{ CONTINUED } & \\
\hline & $\begin{array}{c}\text { Firm investment } \\
\text { in human capital } \\
\text { THC }\end{array}$ & $\begin{array}{l}\text { Monetary value } \\
\text { for firm-specific } \\
\text { training } S H C\end{array}$ & $\begin{array}{c}\text { Share of } \\
\text { firm-specific } \\
\text { training* }\end{array}$ \\
\hline Administrative: sales and distribution & $\begin{array}{c}41319 \\
(35918)\end{array}$ & $\begin{array}{c}4021 \\
(5830)\end{array}$ & $\begin{array}{c}0.14 \\
(0.22)\end{array}$ \\
\hline Administrative: headquarters & $\begin{array}{c}36257 \\
(36459)\end{array}$ & $\begin{array}{l}3288 \\
(2995)\end{array}$ & $\begin{array}{c}0.16 \\
(0.16)\end{array}$ \\
\hline Administrative: banks/insurance & $\begin{array}{c}38766 \\
(29546)\end{array}$ & $\begin{array}{c}6266 \\
(3865)\end{array}$ & $\begin{array}{c}0.25 \\
(0.23)\end{array}$ \\
\hline Other occupations & $\begin{array}{c}50181 \\
(45912)\end{array}$ & $\begin{array}{c}1814 \\
(2433)\end{array}$ & $\begin{array}{c}0.10 \\
(0.20)\end{array}$ \\
\hline \multicolumn{4}{|l|}{ Region } \\
\hline East Germany & $\begin{array}{c}36911 \\
(27826)\end{array}$ & $\begin{array}{c}2496 \\
(3191)\end{array}$ & $\begin{array}{c}0.10 \\
(0.13)\end{array}$ \\
\hline West Germany & $\begin{array}{c}48334 \\
(39423)\end{array}$ & $\begin{array}{c}3479 \\
(4028)\end{array}$ & $\begin{array}{c}0.13 \\
(0.19)\end{array}$ \\
\hline \multicolumn{4}{|l|}{ Institutional setting } \\
\hline Not bound to collective bargaining & $\begin{array}{c}45249 \\
(35412)\end{array}$ & $\begin{array}{c}3436 \\
(4125)\end{array}$ & $\begin{array}{c}0.13 \\
(0.19)\end{array}$ \\
\hline Bound to collective bargaining & $\begin{array}{c}47157 \\
(39922)\end{array}$ & $\begin{array}{c}3172 \\
(3692)\end{array}$ & $\begin{array}{c}0.12 \\
(0.18)\end{array}$ \\
\hline No works council in the firm & $\begin{array}{c}45549 \\
(36145)\end{array}$ & $\begin{array}{c}2932 \\
(3477)\end{array}$ & $\begin{array}{c}0.11 \\
(0.18)\end{array}$ \\
\hline Works council in the firm & $\begin{array}{c}50380 \\
(46448)\end{array}$ & $\begin{array}{c}5494 \\
(5352)\end{array}$ & $\begin{array}{c}0.19 \\
(0.21)\end{array}$ \\
\hline Total & $\begin{array}{c}46240 \\
(37812)\end{array}$ & $\begin{array}{c}3299 \\
(3906)\end{array}$ & $\begin{array}{c}0.12 \\
(0.18)\end{array}$ \\
\hline
\end{tabular}

Source: BIBB-CBS 2007. Standard deviation in parenthesis; all numbers in $€$.

* The values in the third column are the weighted averages of the firms' shares of firm-specific training for each of the subgroups. This value differs from the ratios of the averages of SHC and THC, which are given in the first two columns.

As indicated above, we recalculated the share of firm-specific training under the assumption that wages do not reflect the true productivity of workers due to, e.g. labour market frictions. The results of this «sensitivity» analysis are presented in table A6. Even under the assumption that worker productivity is $50 \%$ higher than the received wage (i.e. $\phi_{i}^{\text {int }}=1.5 * w_{i}^{\text {int }}$ ), we still find only a moderate share of the firmspecific training component of about $16 \%$. In a final step, we estimate a maximumlikelihood selection model to assess whether the differences observed in the descriptive statistics also hold when a set of structural variables is controlled for. For this purpose, we employ the whole set of firms with the censored part of the model being those firms for which information needed for the calculation of the firm-specific training component is available. The results of the model show that both exclusion restrictions are highly significant in the selection model. Because the employment development variable is coded from -2 (strong decrease) to 2 (strong increase), the positive coefficient of the exclusion restriction indicates that employment growth in firms results in higher external recruitment. The positive coefficient of the second 
exclusion restriction variable (i.e. whether firms could fill all vacant apprenticeship training slots) indicates that firms that were not able to fill all vacant training slots have a higher probability of recruiting workers externally. The likelihood ratio test of independence of equations $(\varrho=0)$ indicates that selection is not likely to play a role in our case. We thus receive support in transferring the analysis of the subsample to the full sample of training firms. Table 2 shows the respective regression output of the model. For reference, in table A5, we also present results of the corresponding OLS-regression using only the subsample of recruiting firms.

Table 2: Maximum-likelihood selection model

\begin{tabular}{|c|c|c|c|c|}
\hline & $\begin{array}{c}\text { Share of } \\
\text { specific } \\
\text { component }\end{array}$ & $\begin{array}{l}\text { Standard } \\
\text { error }\end{array}$ & $\begin{array}{l}\text { Recruitment } \\
\text { yes/no }\end{array}$ & $\begin{array}{l}\text { Standard } \\
\text { error }\end{array}$ \\
\hline \multicolumn{5}{|l|}{$\begin{array}{l}\text { Firm size: } \\
\text { Reference «1-9 employees» }\end{array}$} \\
\hline 10-49 employees & 0.025 & $(0.023)$ & $0.304 * * *$ & $(0.067)$ \\
\hline 50-499 employees & $0.075^{* *}$ & $(0.031)$ & $0.552 * * *$ & $(0.086)$ \\
\hline 500+ employees & $0.085 * *$ & $(0.039)$ & $0.550 * * *$ & $(0.128)$ \\
\hline \multicolumn{5}{|l|}{$\begin{array}{l}\text { Vocational field: } \\
\text { Reference «Construction» }\end{array}$} \\
\hline Metalworking & -0.034 & $(0.032)$ & 0.108 & $(0.126)$ \\
\hline Electrical engineering & -0.006 & $(0.034)$ & $-0.221 *$ & $(0.126)$ \\
\hline Information technology & -0.016 & $(0.038)$ & $-0.235^{*}$ & $(0.141)$ \\
\hline Chemicals & -0.061 & $(0.042)$ & $0.284 *$ & $(0.172)$ \\
\hline Accommodation and food & $-0.080 * *$ & $(0.031)$ & -0.068 & $(0.120)$ \\
\hline Print and media & -0.050 & $(0.043)$ & 0.056 & $(0.170)$ \\
\hline Health & -0.059 & $(0.046)$ & -0.143 & $(0.161)$ \\
\hline Administrative: sales/distribution & -0.018 & $(0.033)$ & -0.125 & $(0.124)$ \\
\hline Administrative: headquarters & -0.002 & $(0.031)$ & -0.148 & $(0.114)$ \\
\hline Administrative: banks/insurance & 0.065 & $(0.040)$ & $0.301 *$ & $(0.158)$ \\
\hline Other occupations & 0.001 & $(0.044)$ & -0.075 & $(0.164)$ \\
\hline \multicolumn{5}{|l|}{ Region: Reference «East Germany» } \\
\hline West Germany & 0.018 & $(0.015)$ & -0.077 & $(0.057)$ \\
\hline \multicolumn{5}{|l|}{ Institutional dummies } \\
\hline Works council in the firm & 0.019 & $(0.021)$ & $-0.219 * * *$ & $(0.079)$ \\
\hline Bound to collective bargaining & 0.013 & $(0.015)$ & -0.028 & $(0.056)$ \\
\hline \multicolumn{5}{|l|}{ Exclusion restrictions } \\
\hline Employment development & & & $0.204 * * *$ & $(0.031)$ \\
\hline Unplaced apprenticeships & & & $0.311 * * *$ & $(0.071)$ \\
\hline Constant & 0.104 & $(0.067)$ & $-0.798 * * *$ & $(0.113)$ \\
\hline
\end{tabular}




\begin{tabular}{|c|c|c|c|c|}
\hline & $\begin{array}{c}\text { Share of } \\
\text { specific } \\
\text { component }\end{array}$ & $\begin{array}{c}\text { Standard } \\
\text { error }\end{array}$ & $\begin{array}{c}\text { Recruitment } \\
\text { yes/no }\end{array}$ & $\begin{array}{l}\text { Standard } \\
\text { error }\end{array}$ \\
\hline atrho & -0.022 & $(0.247)$ & & \\
\hline lnsigma & $-1.689 * * *$ & $(0.025)$ & & \\
\hline Observations & 2958 & & & \\
\hline Observations uncensored & 809 & & & \\
\hline \multicolumn{5}{|c|}{ Likelihood-ratio test of independent equations $(\varrho=0): \chi^{2}(1)=0.01$ Prob $>\chi^{2}=0.9355$} \\
\hline
\end{tabular}

Source: BIBB-CBS 2007. $* p<0.10, * * p<0.05, * * * p<0.01$

The results of these calculations confirm the descriptive analysis in that they show that the firm-specific component of training increases with firm size. The respective coefficients of medium and large firms are significant and positive. Furthermore, regression results indicate that compared to the occupational field of construction, occupations in banking and insurance have a higher firm-specific component, with the respective coefficient being just outside the significance level of $10 \%$. On the other hand, occupations in the fields of accommodation and food have lower firmspecific components.

\section{Concluding remarks}

In this paper, we made use of the BIBB-Cost-Benefit-Survey of 2007 to calculate the monetary value of the firm-specific component of apprenticeship training. We argued that the resources needed to bring externally recruited workers to the productivity level of internally trained workers provide a good indicator of the magnitude of the firm-specific component of such training. Measured as a share of total human capital investments, the firm-specific training component is approximately $12 \%$. Recalculating the model under the assumption of imperfect labour markets (i.e. the inequality of productivity and wages) leads to shares of firm-specific training of not more than $16 \%$. These results generally confirm the presumptions made by Acemoglu and Pischke and others, who took German apprenticeship training as a reference for firm investment in general human capital. The maximum-likelihood selection model used in this paper provides some evidence that firm-specificity increases with firm size and that some groups of occupations are trained more (or less) firm-specifically than others. Other variables, such as region, collective bargaining and works councils, seem to be of no importance in the degree of firm-specificity of training.

The results presented in this paper are important from a policy perspective as they confirm that the German apprenticeship system still offers an education that is standardised and transferable, at least within the same occupation and type of job. The low degree of firm-specificity found in this study is surprising, considering that over the past two decades, social partners have worked towards a reduction in the degree of formalisation in training curricula and have allowed firms more freedom to introduce firm-specific training elements. Conversely, in a number of cases, different 
occupations with common sets of tasks and skills were merged, forming a broader occupational field and leading to more general curricula. However, the data used in this paper do not permit an analysis of the change of firm-specificity over time. Newly available individual- and firm-level survey data that provide additional information about skill formation and firms' adjustment processes should facilitate further research in this field.

\section{References}

Acemoglu, D. \& Pischke, J.-S. (1998). Why Do Firms Train? Theory and Evidence. Quarterly Journal of Economics, 113 (1), 79-119

Acemoglu, D. \& Pischke, J.-S. (1999a). Beyond Becker: Training in Imperfect Labour Markets. Economic Journal, 109, F112-F142

Acemoglu, D. \& Pischke, J.-S. (1999b). The Structure of Wages and Investment in General Training. Journal of Political Economy, 107 (3), 539-72

Autor, D. H. (2001). Why Do Temporary Help Firms Provide Free General Skills Training? Quarterly Journal of Economics, 116 (4), 1409-48

Backes-Gellner, U.; Geel, R. \& Mure, J. (2010). Specificity of Occupational Training and Occupational Mobility: An Empirical Study Based on Lazear's Skill-Weights Approach. Education Economics, 18, 1-17

Becker, G. S. (1962). Investment in Human Capital: A Theoretical Analysis. The Journal of Political Economy, 70 (5), 9-49

Beicht, U., Walden, G. \& Herget, H. (2004). Kosten und Nutzen der betrieblichen Berufsausbildung in Deutschland. Bielefeld: Bertelsmann

Bishop, J. (1996). What We Know About Employer-Provided Training: A Review of Literature. Cornell University, School of Industrial and Labor Relations, Center for Advanced Human Resource Studies. CAHRS Working Paper, 96-09. http://digitalcommons.ilr.cornell.edu/cahrswp/180

BMBF (2005). Berufsbildungsgesetz (BBiG). Berlin: BMBF

Bougheas, S. \& Georgellis, Y. (2004). Early Career Mobility and Earnings Profiles of German Apprentices: Theory and Empirical Evidence. Labour, 18 (2), 233-63

Clark, D. (2001). How Transferable is German Apprenticeship Training? Centre for Economic Performance (CEP). London School of Economics

Clark, D. \& Fahr, R. (2002). Transferability, Mobility and Youth Training in Germany and Britain: A Simple Theoretical Analysis. Konjunkturpolitik, 48 (3/4), 235-55

Euwals, R. \& Winkelmann, R. (2004). Training Intensity and First Labor Market Outcomes of Apprenticeship Graduates. International Journal of Manpower, 25 (5), 447-62

Franz, W. \& Soskice, D. (1995). The German Apprenticeship System. In: F. Buttler, W. Franz, R. Schettkat \& D. Soskice (Eds.), Institutional Frameworks and Labour Market Performance. Comparative Views on the U.S. and German Economies, pp. 208-34. London: Routledge

Geel, R. \& Backes-Gellner, U. (2011). Occupational mobility within and between skill clusters: an empirical analysis based on the skill weights approach. Empirical Research in Vocational Education and Training, 3 (1), 21-38

Hashimoto, M. (1981). Firm-Specific Human Capital as a Shared Investment. American Economic Review, 71 (3), 475-82

Heckman, J. J. (1979). Sample Selection Bias as a Specification Error. Econometrica, 47 (1), 153-61

Kessler, A. S. \& Lülfesmann, C. (2006). The Theory of Human Capital Revisited: On the Interaction of General and Specific Investments. Economic Journal, 116 (514), 903-923

Korpi, T. \& Mertens, A. (2003). Training Systems and Labor Mobility: A Comparison between Germany and Sweden. Scandinavian Journal of Economics, 105 (4), 597-617

Lazear, E. P. (2009). Firm-Specific Human Capital: A Skill-Weights Approach. Journal of Political Economy, 117 (5), 914-940

Leuven, E. (2005). The Economics of Private Sector Training: A Survey of the Literature. Journal of Economic Surveys, 19 (1), 91-111 
Pfeifer, H.; Schönfeld, G. \& Wenzelmann, F. (2010). Ausbildungskosten und das Übernahmeverhalten von Betrieben - Ein Vergleich der BIBB-Kosten- und Nutzenerhebungen der Jahre 2000 und 2007. German Review of Social Policy, 59, (6-7), 174-182

Schönfeld, G.; Wenzelmann, F.; Dionisius, R.; Pfeifer, H. \& Walden, G. (2010). Kosten und Nutzen der dualen Ausbildung aus Sicht der Betriebe. Bielefeld: Bertelsmann

Schweri, J. (2006). Das Ausbildungsverhalten Schweizer Firmen: Welche Rolle spielen asymmetrische Information und firmenspezifisches Training? Berlin: dissertation.de

Stevens, M. (1994). A Theoretical Model of On-the-Job Training with Imperfect Competition. Oxford Economic Papers, 46 (4), 537-62

Von Bardeleben, R.; Beicht, U. \& Fehér, K. (1995). Betriebliche Kosten und Nutzen der Ausbildung: Repräsentative Ergebnisse aus Industrie, Handel und Handwerk. Bielefeld: Bertelsmann

Werwatz, A. (1996). How firm-specific is German apprenticeship training? Working Papers. Humboldt University, Sonderforschungsbereich 373

Wolter, Stefan C. \& Ryan, P. (2011). Apprenticeship. In: E. A. Hanushek, S. Machin \& L. Woessmann (Eds.), Handbook of the Economics of Education, Vol. 3, pp. 521-576. North-Holland: Elsevier Science 


\section{Appendix}

Table A1: Descriptive statistics

\begin{tabular}{|c|c|c|c|c|}
\hline & \multicolumn{2}{|c|}{$\begin{array}{l}\text { Firms with recruited } \\
\text { workers }\end{array}$} & \multicolumn{2}{|c|}{ Full sample of firms } \\
\hline & Mean & Std. Dev. & Mean & Std. Dev. \\
\hline \multicolumn{5}{|l|}{ Firm size } \\
\hline 1-9 employees & 0.440 & 0.497 & 0.546 & 0.498 \\
\hline 10-49 employees & 0.380 & 0.486 & 0.329 & 0.470 \\
\hline 50-499 employees & 0.169 & 0.375 & 0.117 & 0.321 \\
\hline $500+$ employees & 0.011 & 0.106 & 0.008 & 0.091 \\
\hline \multicolumn{5}{|l|}{ Vocational field } \\
\hline Metalworking & 0.097 & 0.296 & 0.083 & 0.277 \\
\hline Electrical engineering & 0.083 & 0.276 & 0.098 & 0.297 \\
\hline Information technology & 0.080 & 0.272 & 0.068 & 0.252 \\
\hline Chemicals & 0.026 & 0.159 & 0.011 & 0.102 \\
\hline Accommodation and food & 0.120 & 0.325 & 0.128 & 0.334 \\
\hline Construction & 0.106 & 0.307 & 0.106 & 0.307 \\
\hline Print and media & 0.024 & 0.154 & 0.020 & 0.139 \\
\hline Health & 0.103 & 0.305 & 0.119 & 0.324 \\
\hline Administrative: sales and distribution & 0.132 & 0.339 & 0.138 & 0.344 \\
\hline Administrative: headquarters & 0.169 & 0.375 & 0.187 & 0.390 \\
\hline Administrative: banks/insurance & 0.023 & 0.151 & 0.016 & 0.127 \\
\hline Other occupations & 0.036 & 0.187 & 0.026 & 0.159 \\
\hline \multicolumn{5}{|l|}{ Region } \\
\hline East Germany & 0.183 & 0.387 & 0.165 & 0.371 \\
\hline West Germany & 0.817 & 0.387 & 0.835 & 0.371 \\
\hline \multicolumn{5}{|l|}{ Training organisation } \\
\hline Training centre & 0.073 & 0.260 & 0.047 & 0.212 \\
\hline Internal courses & 0.312 & 0.464 & 0.275 & 0.447 \\
\hline \multicolumn{5}{|l|}{ Institutional setting } \\
\hline Bound to collective bargaining & 0.520 & 0.500 & 0.540 & 0.499 \\
\hline Works councils in the firm & 0.143 & 0.350 & 0.130 & 0.336 \\
\hline Observations & \multicolumn{2}{|c|}{809} & \multicolumn{2}{|c|}{2958} \\
\hline
\end{tabular}

Source: BIBB-CBS 2007 
Table A2: Firm investment in human capital (full apprenticeship)

Firms having recruited workers

\begin{tabular}{lcccc}
\hline & Mean & Std. Dev. & Min & Max \\
\hline Wage costs for trainers in $€$ & 38161 & 35525 & 0 & 215106 \\
Costs for infrastructure in $€$ & 2606 & 3268 & 0 & 49967 \\
Organisational costs in $€$ & 5473 & 5334 & 189 & 42055 \\
Firm investment in human capital in $€$ & 46240 & 37812 & 1350 & 223873 \\
Observations & & & & \\
\hline Full sample of firms & & & & \\
Wage costs for trainers in $€$ & 38125 & 35383 & 0 & 235499 \\
Costs for infrastructure in $€$ & 2649 & 3723 & 0 & 58387 \\
Organisational costs in $€$ & 5147 & 5057 & 0 & 47437 \\
Firm investment in human capital in $€$ & 45921 & 37378 & 0 & 252863 \\
Observations & & & 2958 & \\
\hline
\end{tabular}

Source: BIBB-CBS 2007

Table A3: Variables used for calculating the firm-specific training component of apprenticeship training

Firms having recruited workers

\begin{tabular}{lcccc}
\hline & Mean & $\begin{array}{c}\text { Std. } \\
\text { Dev. }\end{array}$ & Min & Max \\
\hline Monthly wage internally trained worker in $€$ & 1786 & 527 & 500 & 4000 \\
Monthly wage externally recruited workers in $€$ & 1804 & 557 & 500 & 3900 \\
$\begin{array}{l}\text { Productivity difference between externally recruited } \\
\text { and internally trained workers (in per cent) }\end{array}$ & 38 & 22 & 0 & 100 \\
Adjustment time in months & 4 & 4 & 0 & 36 \\
Days spent in continuing training & 21 & 44 & 0 & 243 \\
Costs for fees, etc. of continuing training in $€$ & 424 & 1034 & 0 & 9999 \\
Wage costs of continuing training in $€$ & 752 & 1562 & 0 & 4715 \\
Firm-specific component of training & 3299 & 3906 & 0 & 43727 \\
Observations & & & 809 & \\
\hline
\end{tabular}

Source: BIBB-CBS 2007 
Table A4: Correlation of selection variables

\begin{tabular}{lcc}
\cline { 2 - 3 } & $\begin{array}{c}\text { Employment } \\
\text { development }\end{array}$ & $\begin{array}{c}\text { Unplaced } \\
\text { apprenticeships }\end{array}$ \\
\hline $\begin{array}{l}\text { Productivity difference between externally recruited } \\
\text { and internally trained workers (in per cent) }\end{array}$ & 0.03 & -0.02 \\
$\begin{array}{l}\text { Firm-specific component of training } \\
\text { Observations }\end{array}$ & 0.00 & 0.05 \\
\hline
\end{tabular}

Source: BIBB-CBS 2007

Table A5: OLS-regression model

\begin{tabular}{lcc}
\cline { 2 - 3 } & $\begin{array}{c}\text { Share of specific } \\
\text { component }\end{array}$ & Std. Error \\
\hline Firm size: Reference «1-9 employees» & 0.026 & \\
$10-49$ employees & $0.077^{* * *}$ & $(0.019)$ \\
$50-499$ employees & $0.086^{* *}$ & $(0.023)$ \\
500+ employees & & $(0.033)$ \\
Vocational field: Reference «Construction» & -0.034 & \\
Metalworking & -0.007 & $(0.032)$ \\
Electrical engineering & -0.017 & $(0.034)$ \\
Information technology & -0.060 & $(0.038)$ \\
Chemicals & $-0.080^{*}$ & $(0.041)$ \\
Accommodation and food & -0.050 & $(0.031)$ \\
Print and media & -0.060 & $(0.043)$ \\
Health & -0.018 & $(0.046)$ \\
Administrative: sales and distribution & -0.003 & $(0.033)$ \\
Administrative: headquarters & 0.066 & $(0.031)$ \\
Administrative: banks/insurance & 0.000 & $(0.039)$ \\
Other occupations & & $(0.044)$ \\
Region: Reference «East Germany» & & \\
West Germany & 0.018 & $(0.015)$ \\
Institutional dummies & & \\
Works councils in the firm & & $(0.020)$ \\
Bound to collective bargaining & 0.018 & $(0.015)$ \\
Constant & 0.012 & $(0.030)$ \\
Observations & $0.099^{* *}$ & \\
\hline
\end{tabular}

Source: BIBB-CBS 2007. $* p<0.10, * * p<0.05, * * * p<0.01$ 
Table A6: Alternative estimation of share using hypothetical wage-productivity differentials

\begin{tabular}{lcc}
\hline Share of specific component & Mean & Std. Dev. \\
\hline$\phi_{\mathrm{i}}^{\text {int }}=w_{\mathrm{i}}^{\text {int }}$ & 0.12 & 0.17 \\
$\phi_{\mathrm{i}}^{\text {int }}=1.1 * w_{\mathrm{i}}^{\text {int }}$ & 0.13 & 0.19 \\
$\phi_{\mathrm{i}}^{\text {int }}=1.25 * w_{\mathrm{i}}^{\text {int }}$ & 0.14 & 0.20 \\
$\phi_{\mathrm{i}}^{\text {int }}=1.5 * w_{\mathrm{i}}^{\text {int }}$ & 0.16 & 0.20
\end{tabular}

Figure A1: Unemployment and job vacancies in Germany (in 1000s)

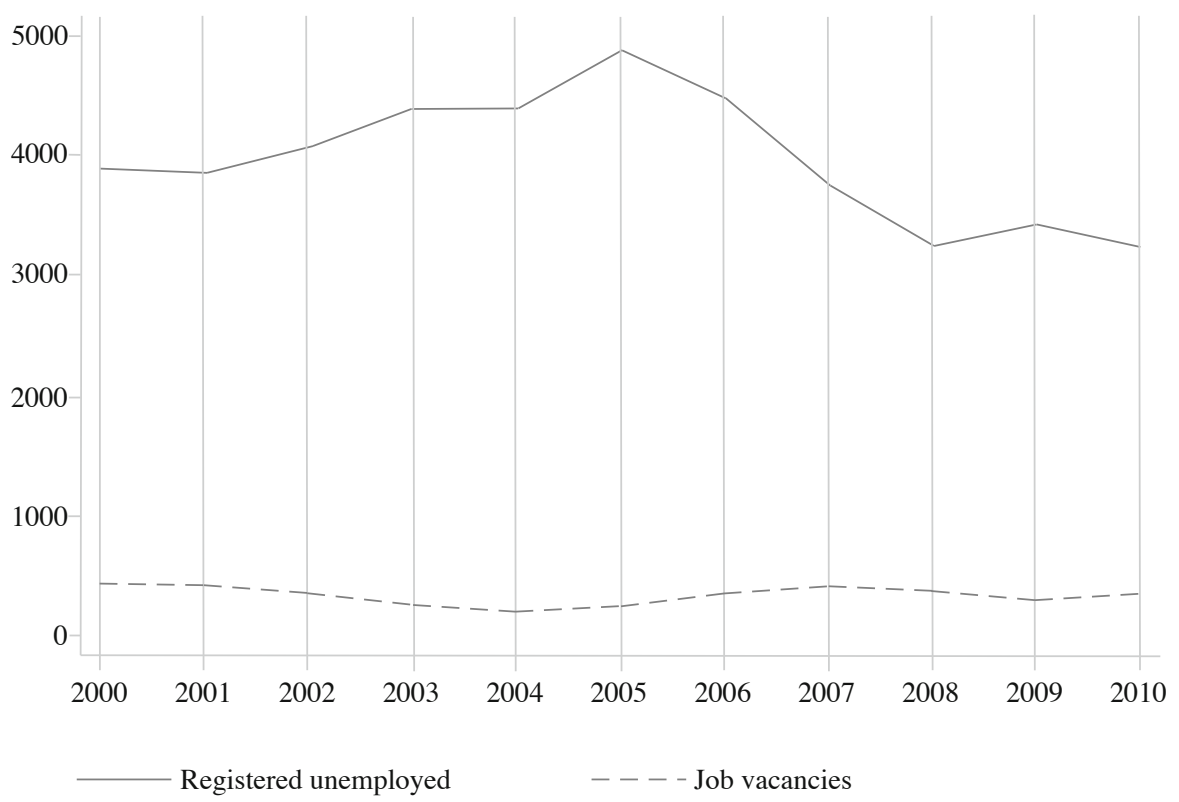

Data source: Federal Employment Ageny, Germany 